Bonnar, J. McNicol, G. P., and Douglas, A. S. (1971). British Medical fournal, 2, 12.

Clark, A. D. (1974). Proceedings of the 6th Meeting of Organisation Gestosis, Glasgow. In press. Dacie, J. V., and Lewis, S. M. (1963). Practical Haematology, 3rd edn.,
London, Churchill.

Farrell, G. W., and Wolf, P. (1971 a). Fournal of Immunological Methods. 1, 217. Farrell, G. W., and Wolf, P. (1971 b). Medical Laboratory Technology, 28, 328. Farrell, G. W., and Wolf, P. (1973). Fournal of Clinical Pathology, 26, 764. Henderson, A. H., Pugsley, D. J., and Thomas, D. P. (1970). British Medical fournal, 3, 545 .

Howie, P. W., Prentice, C. R. M., and McNicol, G. P. (1971). fournal of Obstetrics und Gynaecology of the British Commonwealth, 78, 992 .

Howie, P. W. (1974). Proceedings of the 6th Meeting of Organisation Gestosis, Glasgow. In press.

Kunz, S., Weber, H., Horvath, T., Heller, S., and Kidess, E. (1974)., Proceedings of the 6th Meeting of Organisation Gestosis, Glasgow. In press.
Laurell, C.-B. (1966). Analytical Biochemistry, 15, 45.

McKay, D. G., and Corey, A. F. (1964). Obstetrics and Gynecology, 23, 508. Page, E. W. (1972). Fournal of Obstetrics and Gynaecology of the British Commoni:ealth, 79. 883 .

Pritchard, J. A., Ratnoff, O. D., and Weisman, R. (1954). Obstetrics and Gynecology, 4, 159.

Schneider, C. L. (1947). American fournal of Phvsiology, 149, 123.

Shainoff, J. R., and Page, I. H. (1962). Fournal of Experimental Medicine, 116, 687.

Stahnke, E. (1922). Zentralblatt für Gynäkologie, 46, 391

Wardle, E. N., and Menon, I. S. (1969). British Medical fournal, 2, 625

Whipple, G. H. (1914). American fournal of Physiology, 33, 50.

Wolf, P., Farrell, G. W., and Walton, K. (1972). Fournal of Clinical Pathology 25,36 .

Wclf, P., and Farrell, G. W. (1972). In Methods of Microcirculation Studies, ed. T. J. Ryan, B. Jolles, and G. Holti, p. 92. London, H. K. Lewis. Wood, S. M., (1974). M.D., Thesis submitted to University of Birmingham.

\title{
Tetracycline Poisoning in Renal Failure
}

\author{
M. E. PHILlipS, J. B. EASTWOOD, J. R. CURTIS, P. E. GOWER, H. E. DE WARDENER
}

Case 1

A 31-year-old woman had suffered from Still's disease for 27 years. In 1954, at the age of 15, she was found to have amyloidosis and proteinuria with a blood urea of $22 \mathrm{mg} / 100 \mathrm{ml}$. By March 1969 the blood urea had risen to $77 \mathrm{mg} / 100 \mathrm{ml}$. In November 1969 she developed a urinary infection and a ureteric caloulus which she passed spontaneously. Renal function had deteriorated, so that when she left hospital the blood urea was $160 \mathrm{mg} / 100 \mathrm{ml}$. In May 1970 she developed an infection of her gums and was treated with tetracycline $1 \mathrm{~g} /$ day by her dentist. She developed nausea, diarrhoea, lethargy, dyspnoea, and severe leg cramps. Six days after starting tetracycline she was admitted to hospital as an emergency case. She was dehydrated and hypotensive. The plasma sodium was $135 \mathrm{mEq}$, potassium $5.7 \mathrm{mEq}$, and bicarbonate 18 $\mathrm{mEq} / 1$; ; and the blood urea was $315 \mathrm{mg}$ and creatinine $9.1 \mathrm{mg} / 100$ $\mathrm{ml}$. A Teflon Silastic shunt was inserted into the left leg and haemodialysis performed. She remained very ill and within a few days her left foot became cold and white. A lumbar sympathectomy was performed, after which she required artificial ventilation, had a gastrointestinal haemorrhage, and died. Necropsy showed renal and hepatic amyloidosis, gastric ulceration, and pneumonia. There was no evidence of renal calculi or pyelonephritis.

\section{Case 2}

A 45-year-old man with polycystic kidneys was investigated in 1966. On a $20-\mathrm{g}$ protein diet his blood urea was $66 \mathrm{mg} / 100 \mathrm{ml}$ and his plasma creatinine $11.5 \mathrm{mg} / 100 \mathrm{ml}$. Two months later he developed sinusitis and was treated at home for five days with oxytetracycline $1 \mathrm{~g} /$ day. He developed nausea, vomiting, abdominal pain, and diarrhoea. He stopped the drug and came to hospital. The blood urea was $140 \mathrm{mg} / 100 \mathrm{ml}$ and the plasma creatinine $14.8 \mathrm{mg} / 100 \mathrm{ml}$. He was treated with intravenous saline, antiemetics, and a low-protein diet. The symptoms improved after 48 hours but the plasma creatinine continued to rise and after 10 days maintenance haemodialysis was begun. Renal transplantation was performed three years later. we subject (British Medical fournal, 1972). This paper is written to show that tetracycline produces an impairment of renal function in patients with existing renal disease which is not always reversible and may be fatal.

Charing Cross Hospital Medical School, London W6 8RF

M. E. PHILLIPS, M.B., M.R.C.P., Research Fellow, Department of Medicine I. B. EASTWOOD, M.B., M.R.C.P., Lecturer in Medicine J. R. CURTIS, M.D., F.R.C.P., Senior Lecturer in Medicine J. R. CURTIS, M.D., F.R.C.P., Senior Lecturer in Medici P. E. GOWER, M.D., M.R.P.P., Consultant Nephrologist
H. E. DE WARDENER, M.D., F.R.C.P., Professor of Medicine

\section{Case 3}

This 33-year-old man presented in 1968 with vomiting, headaches, blurred vision, thirst, and nocturia. He was found to have hypertension with papilloedema. The plasma creatinine was $5 \mathrm{mg} / 100$ $\mathrm{ml}$ and the blood urea $130 \mathrm{mg} / 100 \mathrm{ml}$. Renal arteriography showed left renal artery obstruction. At laparotomy this was found to be due to a fibrous band. When this was divided pulsation returned. Postoperatively he became oliguric and required haemodialysis for three to four weeks. Renal function then 
improved and he was discharged on a $20-\mathrm{g}$ protein diet. The blood urea was $124 \mathrm{mg} / 100 \mathrm{ml}$ and the plasma creatinine 5.9 $\mathrm{mg} / 100 \mathrm{ml}$. For four years he was treated as an outpatient. The hypertension was well controlled with methyldopa. He did not follow the diet and was eventually on a 70-80-g protein diet. During these four years the plasma creatinine rose only from 6.5 to $7.5 \mathrm{mg} / 100 \mathrm{ml}$ and the blood urea from 180 to $220 \mathrm{mg} / 100$ $\mathrm{ml}$ (see chart).

In November 1972 he developed influenza. His doctor prescribed oxytetracycline $1 \mathrm{~g} /$ day. After one week he returned to his doctor with weakness, anorexia, nausea, and vomiting. A further course of the same drug was supplied. A week later he was admitted to hospital. He was extremely dehydrated, his weight being $7 \cdot 3 \mathrm{~kg}$ less than when last seen three months earlier. The blood pressure was $130 / 70 \mathrm{~mm} \mathrm{Hg}$. He was hyperpnoeic and his plasma bicarbonate was $9 \mathrm{mEq} / 1$. The blood urea was $490 \mathrm{mg} / 100 \mathrm{ml}$ and the plasma creatinine $15.6 \mathrm{mg} / 100 \mathrm{ml}$. He was treated with intravenous saline and sodium bicarbonate. When the vomiting stopped he was able to take a high-calorie, low-protein diet. He recovered slowly. On a normal diet at the time of discharge one month after admission his blood urea was $180 \mathrm{mg} / 100 \mathrm{ml}$ and his plasma creatinine $9 \mathrm{mg} / 100 \mathrm{ml}$. During the next four months renal function deteriorated at a much faster rate than previously, and in April 1973 he was placed on maintenance haemodialysis.

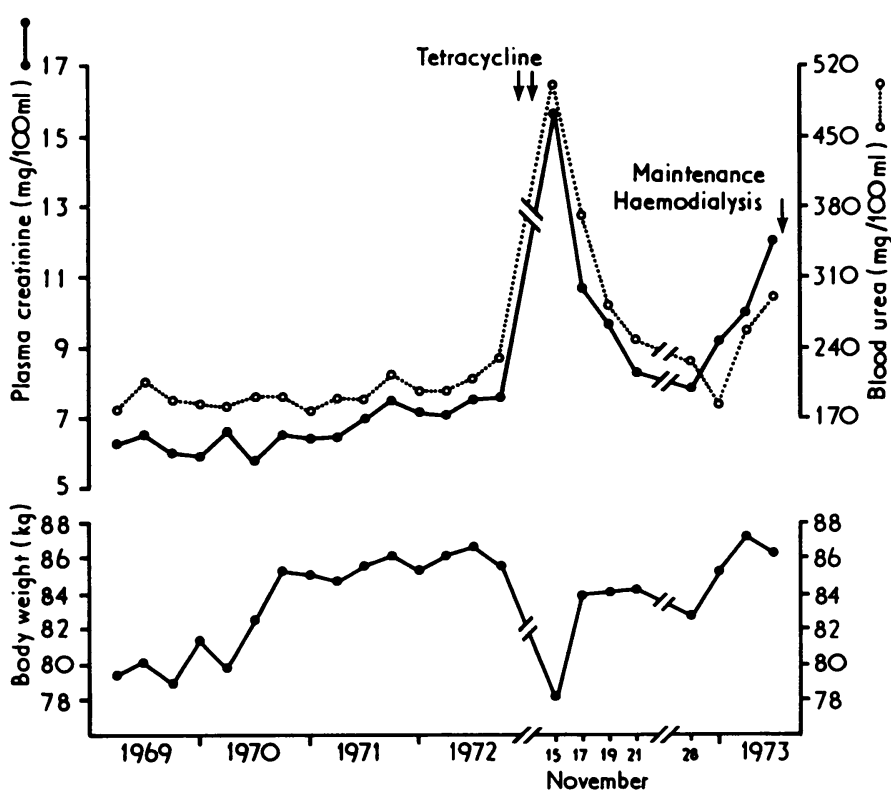

Case 3. Rise in plasma creatinine and blood urea with accompanying weight loss induced by tetracycline in patient with chronic renal failure.

\section{Case 4}

A 38-year-old Ghanaian man was admitted to his local hospital with a three-day history of abdominal pain and vomiting. On clinical and biochemical grounds a diagnosis of acute pancreatitis was made. The blood urea was $180 \mathrm{mg} / 100 \mathrm{ml}$. He was treated with a "drip-and-suck" regimen which included intravenous tetracycline $2 \mathrm{~g} /$ day. He did not become anuric. After five days the blood urea rose to $400 \mathrm{mg} / 100 \mathrm{ml}$ and he was flown to London. The intravenous infusion of tetracycline had continued uninterruptedly during the journey. When he arrived the blood urea was $600 \mathrm{mg} / 100 \mathrm{ml}$ and the plasma creatinine $17.2 \mathrm{mg} / 100$ ml. Tetracycline was stopped and peritoneal dialysis was begun. After 48 hours the blood urea fell to $200 \mathrm{mg} / 100 \mathrm{ml}$ and thereafter he was managed with a high-calorie, low-protein diet and made a slow recovery. At the time of discharge six weeks after admission his blood urea was $41 \mathrm{mg} / 100 \mathrm{ml}$ and his plasma creatinine $1.2 \mathrm{mg} / 100 \mathrm{ml}$.

\section{Case 5}

A 49-year-old Australian man had had chronic renal failure of unknown aetiology for two years. Immediately before sailing to England his plasma creatinine was $7 \mathrm{mg} / 100 \mathrm{ml}$ and he developed dysuria and was given antibiotics. On the boat the treatment was changed to tetracycline $1 \mathrm{~g} /$ day. He came to hospital three days after landing, by which time he had been taking tetracycline for eight days. On admission he had hicups and excoriations and was jumpy and irritable. The blood urea was $309 \mathrm{mg} / 100 \mathrm{ml}$ and the plasma creatinine $10.6 \mathrm{mg} / 100 \mathrm{ml}$. Despite treatment with intravenous saline and sodium bicarbonate the blood urea rose to $406 \mathrm{mg} / 100 \mathrm{ml}$ and the plasma creatinine to $13 \cdot 1 \mathrm{mg} / 100 \mathrm{ml}$. Peritoneal dialysis was begun and continued for 76 hours. At the end of this time the blood urea was still $200 \mathrm{mg} / 100 \mathrm{ml}$ but he was then able to take a $20-\mathrm{g}$ protein diet and made a gradual recovery. When discharged one month after admission his blood urea was $74 \mathrm{mg} / 100 \mathrm{ml}$ his plasma creatinine $9.5 \mathrm{mg} / 100 \mathrm{ml}$.

\section{Case 6}

In February 1971 a 69 -year-old man was investigated at another hospital for anorexia, nausea, and loss of weight. He was found to have proteinuria and a blood urea of $120 \mathrm{mg} / 100 \mathrm{ml}$. An appointment was made for him at this hospital but he went on holiday and developed acute bronchitis which was treated with oxytetracycline $1 \mathrm{~g} /$ day. Five days later he developed severe vomiting and was admitted here. On admission he was oliguric, with plasma sodium $147 \mathrm{mEq}$, potassium $7.4 \mathrm{mEq}$, and bicarbonate $14 \mathrm{mEq} / 1$; and a blood urea of $342 \mathrm{mg}$ and a creatinine of $23.6 \mathrm{mg} / 100 \mathrm{ml}$. He was treated with peritoneal dialysis and developed pericarditis and gastrointestinal bleeding. He gradually improved, however, and was discharged six weeks after admission on a 30-g protein diet. The blood urea was $156 \mathrm{mg} / 100 \mathrm{ml}$ and the plasma creatinine $9.9 \mathrm{mg} / 100 \mathrm{ml}$.

\section{Case 7}

In 1969 a 48-year-old woman was found to have retroperitoneal fibrosis and bilateral hydronephrosis. The obstruction was relieved by constructing an ileal conduit. She also suffered from diabetes mellitus, hypertension, and recurrent urinary tract infections. In 1970 the blood urea was $68 \mathrm{mg} / 100 \mathrm{ml}$ and the plasma creatinine $2.3 \mathrm{mg} / 100 \mathrm{ml}$. In February 1972 renal function had shown little deterioration, with a blood urea of $70 \mathrm{mg} / 100 \mathrm{ml}$ and a plasma creatinine of $2.5 \mathrm{mg} / 100 \mathrm{ml}$.

In November 1972 she developed fever, a non-productive cough, and retrosternal pain worsened by deep inspiration. Her doctor prescribed tetracycline $1 \mathrm{~g} /$ day. Next day she began vomiting and this persisted for three days. She then developed watery diarrhoea and was admitted to hospital two days later. The initial biochemical findings were: plasma sodium $132 \mathrm{mEq}$, potassium $3 \cdot 1$ $\mathrm{mEq}$, and bicarbonate $9 \mathrm{mEq} / \mathrm{l}$; creatinine $5.3 \mathrm{mg}$, urea $145 \mathrm{mg}$, and glucose $265 \mathrm{mg} / 100 \mathrm{ml}$; and arterial $\mathrm{pH} 7 \cdot 19$. The urine was sterile. She was treated with intravenous saline, sodium bicarbonate, and potassium chloride. After one week the blood urea was 56 $\mathrm{mg} / 100 \mathrm{ml}$ and the plasma creatinine $3.9 \mathrm{mg} / 100 \mathrm{ml}$. In January 1973 the blood urea was $98 \mathrm{mg} / 100 \mathrm{ml}$ and the plasma creatinine $3 \cdot 1 \mathrm{mg} / 100 \mathrm{ml}$.

\section{Discussion}

The danger of prescribing tetracycline to patients with chronic renal failure is not generally appreciated. There is a misguided notion that in renal failure the administration of tetracycline may cause only a harmless and reversible rise in blood urea without reducing the glomerular filtration rate (Van Ypersele de Strihou, 1970; Dijkhuis and Van Meurs 1973). It is apparent from the cases described above that the adverse effects of tetracycline in renal failure are not uncommon and that the glomerular filtration rate is reduced, sometimes irreversibly. This view accords with the observations of others Wray et al., 1965; Hanson, 1968; Perkash et al., 1969; Eastwood, et al., Edwards et al., 1970; Brown, 1971; George and Evans, 1971; Curtis, 1972). Less severe effects of tetracyclines on the renal function of normal subjects have also been des- 
cribed (Roth et al., 1967). The impairment of renal function is ruite distinot from the rarely-seen, Fanconi-like syndrome produced by a degradation product of tetracycline (anhydro-4epitetracycline) formed from improper storage of tetracycline. This syndrome was harmless and fully reversible (Benitz and Diermeier, 1964).

There is a monotonous regularity in the sequence of clinical events associated with the prescribing of tetracycline to patients with chronic renal failure. The patient develops a minor infection, often respiratory; he seeks medical advice and is given tetracycline in normal amounts. He soon develops anorexia, nausea, and vomiting and sometimes diarrhoea. His condition rapidly deteriorates and he becomes dehydrated, hypotensive, and acidotic. He is then referred to hospital as an emergency case and often arrives still taking tetracycline. Treatment with intravenous saline and bicarbonate may suffice to control his symptoms but peritoneal dialysis may have to be performed. He may recover but renal function may remain so depressed that he has to be placed on maintenance haemodialysis.

There are a number of mechanisms by which tetracycline can affect renal function. Shils (1963) suggested that inhibition of intracellular protein synthesis occurs. This leads to decreased amino-acid utilization and subsequently to a rise in blood urea. Shils also noted that tetracyclines cause increased sodium excretion and a loss of weight. It is possible, therefore, that another cause for the rise in blood urea is a reduction in glomerular filtration rate due to volume depletion. Roth et al. (1967) reported a reduction in creatinine clearance and impaired ability to concentrate the urine in two out of six healthy subjects taking dimethylchlortetracycline. Other workers have reported a vasopressin-resistant diabetes insipidus associated with ingestion of this drug (Pijnenburg, 1966; Torin, 1967; Maxon and Rutsky, 1973). The use of tetracycline should therefore be avoided not only in patients with renal failure but also in those who are dehydrated, for it will increase the salt and water deficiency and ultimately produce renal failure. This point is well illustrated by case 4 . It is probable that the patient developed acute renal failure as a complication of acute pancreatitis. Tetracycline cannot be blamed as the primary cause of the renal impairment but in view of its natriuretic and diuretic effects it may well have caused a further deterioration in renal function.

In addition to their metabolic effects tetracyclines may cause anorexia, nausea, vomiting, and diarrhoea. In renal failure the half life of these drugs (other than doxycycline) is increased (Kunin, 1967), so that the metabolic and gastrointestinal side effects will be more severe and prolonged. The deterioration in renal function produced in case 5 was not corrected by salt and water replacement, and 76 hours of peritoneal dialysis produced only a $50 \%$ fall in blood urea.

Two or three of our patients (cases 1, 6, and possibly 5) were given tetracycline by persons who were perhaps unaware of the presence of renal failure. We suggest that to safeguard such patients they should carry a card-"I am a patient with chronic renal failure. I must not be given the following drugs: tetracycline hydrochloride (Achromycin, Ambramycin, Clinitetrin, Co-Caps Tetracycline, Economycin, Steclin, Sustamycin, Telotrex, Tetrabid-Organon, Tetracyn, Totomycin); chlortetracycline hydrochloride (Aureomycin); oxytetracyline (Abbocin, Berkmycen, Clinimycin, Ethoxytet, Galenomycin, Imperacin, Oxydon, Oxymycin, Oxytetrin, Terramycin, Ticycline, Unimycin); dimethylchlortetracycline (Ledermycin); methacycline (Rondomycin); lymecycline (Armyl, Tetralysal)."

A number of preparations containing tetracyclines in combination with other drugs should also be added-for example, Lederstatin, Mysteclin (with nystatin); Terramycin S.F., Tetracyn S.F. (with vitamins). Other drugs could also be included on the card-for example, digoxin, ethacrynic acid, nitrofurantoin, chloramphenicol, phenformin.

Tetracyclines were prescribed to some of the patients described above in spite of the fact that all those concerned with the care of the patients were aware that they suffered from chronic renal failure. Cases 2 and 3 had well-documented advanced renal failure, and one of these patients (case 3), who had had stable renal function for four years, was given two consecutive courses of tetracycline. Both patients had to be treated with maintenance haemodialysis sooner than expected.

The increasing number of reports of the ill effects of tetracycline in patients with chronic renal failure raises the passibility that the continuation of this practice may eventually lead to medicolegal complications. Perhaps this would have more effect in publicizing this problem than the more usual forms of medical communication. There is now no reason for using the tetracyclines listed above for patients with renal failure. Doxycycline, which is one of the same group and has similar antibacterial properties and spectrum, does not cause a rise in blood urea (Little and Bailey, 1970) and has a half life in patients with renal failure equal to that in normal subjects (Mérier et al., 1969-70; Mahon et al., 1970).

Request for reprints should be addressed to: Dr. M. E. Phillips, Department of Medicine, Charing Cross Hospital, London W6 8RF.

\section{References}

Bateman, J. C., Barberio, J. R., Grice, P., Klopp, C. T., and Pierpont, H. (1952). Archives of Internal Medicine, 90,763 .

Benitz, K. F., and Diermeier, H. F. (1964). Proceedings of the Society for Experimental Biology and Medicine, 115, 930.

British Medical fournal, 1972, 1, 370.

British Medical fournal, 1972, 1, 370.

Brown, C. B. (1971). British Medical fournal, 4, 428
Curtis, J. R. (1972). British Medical fournal, 1, 52.

Dijkhuis, H. J. P. M., and Van Meurs, A. J. (1973). fournal of the American Medical Association, 223, 441.

Eastwood, J. B., Bailey, R. R., Curtis, J. R., Gower, P. E., and de Wardener, H. E. (1970). Lancet, 2, 39.

Edwards, O. M., Huskisson, E. C., and Taylor, R. T. (1970). British Medical fournal, $1,26$.

George, C. R. P., and Evans, R. A. (1971). Medical fournal of Australia, 1,1271 .

Hanson, G. C. (1968). Postgraduate Medical fournal, 44, 870.
Keenan, T. D., Blacklock, H., Little, P. J., and Bailey, R. R. (1973). New Zealand Medical fournal, 78, 764 .

Kunin, C. M. (1967). In Proceedings of 3rd International Congress of Nephrology, Prague 1967, ed. G. J. Schreiner, vol. 3, p. 193. Basel, Karger. Little, P. J., and Bailey, R. R. (1970). New Zealand Medical fournal, 72, 183. Mahon, W. A., Wittenberg, J. V. P., and Tuffnel, P. G. (1970). Canadian Medical Association fournal, 103, 1031.

Maxon, H. R., and Rutsky, E. A. (1973). Military Medicine, 138, 500.

Mérier, G. Laurencet, F. L., Rudhardt, M., Chuit, A., and Fabre, J. (196970). Helvetica Medica Acta, 35, 124.

Perkash, I., Kataria, P. N., and Khanna, O. P. (1969). Fournal of Urology, $102,102$.

Pijnenburg, L. E. M. (1966). Nederlandsch Tijdschrift Voor Geneeskunde, $110,318$.

Roth, H., Becker, K. L., Shalhoub, R. J., and Katz, S. (1967). Archives of Internal Medicine, 120, 433.

Shils, M. E. (1963). Annals of Internal Medicine, 58, 389.

Torin, D. E. (1967). Califormia Medicine, 107, 420.

Van Ypersele de Strinhou, C. (1970). Lancet, 2, 208.

Womack, C. R., et al. (1952). Archives of Internal Medicine, 89, 240

Wray, S. H., Kocen, R. S., and Wright, K. J. (1965). Postgraduate Medical Fournal, 41, 18. 